www.jmscr.igmpublication.org

Impact Factor (SJIF): 6.379

Index Copernicus Value: 71.58

ISSN (e)-2347-176x ISSN (p) 2455-0450

crossref DOI:_https://dx.doi.org/10.18535/jmscr/v6i4.04

Journal Of Medical Science And Clinical Research

IGM Publication

An Official Publication of IGM Publication

\title{
Platelet disorders is common cause of bleeding manifestation pediatrics age group -study at tertiary heath care center CNBC \& M.Y. Hospital Indore
}

\author{
Authors \\ Dr Shailendra Singh Thakur ${ }^{1}$, Dr C.V.Kulkarni \\ ${ }^{1}$ Assit. Prof, CNBC \& AK, ${ }^{2}$ Prof \& Head \\ M.G.M. Medical College with M.Y.H. Indore MP \\ Corresponding Author \\ Dr Shailendra Singh Thakur \\ Email-shailen.dt@gmail.com
}

\begin{abstract}
Objectives \& Aims: 1) To determine the hematological findings \& coagulation profile of the study subjects. 2) To find out relevant clinical findings of study subjects through clinical examination \& detail history. 3) To find the correlation of the clinical findings with the hematological findings studied. To establish probable diagnosis in the study subjects. To find the incidence of spectrum of diseases in bleeding disorders. To find the age and sex distribution of the cases studied.

Material \& Methods: Blood was collected in a sterile EDTA containing tube and processed following our established hospital based laboratory protocol. A complete blood counting including HB\%, PCV, Red cell indices, platelet count, total white cell count done by Automated blood cell counter. The all cell count indices including RBC, WBC count with differential along with morphological changes further confirmed by manual oil immersion smear study method. Peripheral smears study was done with field A and B stain and leishman stain.

Conclusion: This In our study we found that in most of the cases of thrombocytopenia i.e below 1,50000 count $(81 \%)$, automated counter give very low platelet counts while on peripheral smear examination, the count is not that much reduced but different morphological variations of platelets like megathrombocytes, platelet aggregates and platelet fragments are found. These variations denote inactive or non functional platelets, hence despite of the low normal or near normal platelet counts, patient present with bleeding.
\end{abstract}

\section{Material \& Methods}

Study area and design- This present study was conducted at the CNBC hospital is a part of MGM Medical College with M.Y. Hospital Indore MP. The study was designed as a observational retrograde with prospective hospital based study over a period of time from 2016 to 2018 years.
Ethical consideration- Blood was collected in a sterile EDTA tube and plaint tube and processed following our established laboratory protocol then generate the report of each patient. Take informed consent was obtained from all study participant for use of your blood sample for medical research after doing physician request investigating and generate the report.

Patient's selection criteria-The study target all 
patients on the basis of clinical signs, symptoms and, history by attainder. We include both emergency and IPD patients with all groups, male and female both gender for study. Sample size is 100 patients.

Laboratory investigations Blood was collected in a sterile EDTA containing tube and processed following our established laboratory protocol .A complete blood counting including $\mathrm{HB} \%$, PCV, Red cell indices, platelet count and total white cell count and differential was done by Automated blood cell counter and peripheral blood smear examination. The all cell count indices including RBC, WBC count with differential along with morphological changes further confirmed by manual oil immersion smear study method. Peripheral smears study was done with field A and B stain and leishman stain.

\section{Materials}

Purple vacutainer tube or capillary collector (EDTA) ethylenediaminetetraacetate, Slides and blue capillary tube, Needle or lancet, Vacutainer holder, Alcohol swab, Cotton balls, Absorbent materials, Slide case and heamatological cell counter.

\section{Procedure}

Specimen is collected into EDTA (purple) vacutainer.

Laboratory investigations- Blood was collected in a sterile EDTA containing tube and processed following our established laboratory protocol

A complete blood counting including $\mathrm{HB} \%, \mathrm{PCV}$, Red cell indices ,platelet count and total white cell count and differential was done by Automated blood cell counter analyzer of all the patient on antiretroviral therapy .The all cell count indices including WBC count with differential and platelet count, was further confirmed by manual oil immersion smear study method. Peripheral smears study was done with field A and B stain and leishman stain.

\section{Hematological examination}

Hematological examination including $\mathrm{HB} \%$, PCV, Red cell indices, platelet count and total white cell count with differential count should be done on peripheral smears stained with field A and B stain and leishman stain.

\section{Observation \& Discussion}

Platelets, or Thrombocytes

(from Greek thrombus- «clot» and cyte«cell»)

- Platelets are produced in blood cell formation (thrombopoiesis) in bone marrow, by budding off from megakaryocytes.

- The physiological range for platelets is 150,000-400,000/cu mm.

- Around 1 x 1011 platelets are produced each day by an average healthy adult.

- The lifespan of circulating platelets is 5 to 9 days.

- The platelets arise from the fragmentation of the megakaryocytes in the bone marrow and circulate in blood as disc-shaped anucleate particles. Megakaryocyte and platelet production is regulated by thrombopoietin, a hormone usually produced by the liver and kidneys.

- Each megakaryocyte produces between 5,000 and 10,000 platelets.

- Old platelets are destroyed by phagocytosis in the spleen and by Kupffer cells in the liver.

- A reserve of platelets are stored in the spleen and are released when needed by sympathetically-induced splenic contraction.

\begin{tabular}{|l|c|}
\hline Prolonged tests & $\begin{array}{c}\text { No of cases } \\
(\mathbf{n = 1 0 0})\end{array}$ \\
\hline Bleeding time $(>8 \mathrm{~min})$ & $35(35 \%)$ \\
\hline Clotting time $(>9 \mathrm{~min})$ & $30(30 \%)$ \\
\hline Prothrombin time $(>20 \mathrm{secs})$ & $23(23 \%)$ \\
\hline $\begin{array}{l}\text { Partial thromboplastin time }(>40 \\
\text { secs })\end{array}$ & $12(12 \%)$ \\
\hline
\end{tabular}

Bleeding time is prolonged in 35/100 patients $(36 \%)$ while clotting time in $30 / 100$ patients $(30 \%)$. Prolonged prothrombin time is seen in 23/100 study cases (23\%) where as activated partial thromboplastin time is inceased in $12 / 100$ cases $(12 \%)$. 


\begin{tabular}{|l|c|c|c|c|}
\hline Age in yrs & Number of males & $\begin{array}{c}\text { \% of males } \\
(\mathbf{n}=\mathbf{4 0})\end{array}$ & $\begin{array}{c}\text { Number of } \\
\text { females }\end{array}$ & $\begin{array}{c}\text { \% of females } \\
(\mathbf{n}=\mathbf{4 8})\end{array}$ \\
\hline $0-10$ & 40 & 40 & 05 & 05 \\
\hline $11-20$ & 47 & 47 & 08 & 08 \\
\hline
\end{tabular}

most commonly affected age group is found to be 11-20 years

\begin{tabular}{|l|c|c|}
\hline Hematological disorders & $\begin{array}{c}\text { Total no. } \\
\text { of cases }\end{array}$ & $\begin{array}{c}\text { \% } \\
(\mathbf{n = 1 0 0})\end{array}$ \\
\hline Idiopathic thrombocytopenic purpura & 23 & \\
\hline Aplastic anemia & 15 & \\
\hline Myelodysplastic syndrome & 7 & \\
\hline Non Hodgkins lymphoma & 1 & \\
\hline Sickle cell anemia & 6 & \\
\hline Hemophilia & 6 & \\
\hline Malaria Intravascular & 9 & \\
\hline $\begin{array}{l}\text { Disseminated } \\
\text { coagulation }\end{array}$ & 2 & \\
\hline Nutritional anemia & 7 & \\
\hline Liver disease & 5 & \\
\hline Vitamin K deficiency & 7 & \\
\hline Acute myeloid Leukemia & 3 & \\
\hline Acute lymphoid Leukemia & 5 & \\
\hline Chronic myelogenous leukemia & 2 & \\
\hline Chronic lymphoblastic leukemia & 1 & \\
\hline
\end{tabular}

\section{Result}

Univariate analysis showed that there were significant associations of platelets disorder and bleeding manifestation, mild to marked type changes these various bleeding manifestation changes cause the raised distribution use as a prognostic tool for survival index outcome of patients. Kruskal-Wallis tests revealed an association of raised with severity survival index patients: $p<0.0001, \quad$ (Wilcoxon test: $p=0.002$ ). multivariate analysis showed is a significant prognostic factor $(p=0.040)$.

\section{Conclusion}

In our study we found that in most of the cases of thrombocytopenia i.e below 1,50000 count $(81 \%)$, automated counter give very low platelet counts while on peripheral smear examination, the count is not that much reduced but different morphological variations of platelets like megathrombocytes, platelet aggregates and platelet fragments are found. These variations denote inactive or non functional platelets, hence despite of the low normal or near normal platelet counts, patient present with bleeding.

It is also our observation that many patients having hemostatic disorders do not necessarily have prolonged bleeding or clotting time which means that hemostasis is dependent on many other unknown in vitro (technical considerations) or in vivo (over the counter drugs) factors.

Our endeavour here is to evaluate bleeding disorders on the available resources in the department and help the clinicians to have an idea of the hematological changes seen on light microscopy, for deciding the treatment of the diseases.

\section{References}

1. Acute immune thrombocytopenia (ITP) in childhood: retrospective and prospective survey in Germany ; Sutor AH, Harms A

2. Aetiological considerations of acquired aplastic Anaemia; Saqib Malik, Iram Sarwar

3. Age and the Prevalence of Bleeding Disorders in Women With Menorrhagia ;Philipp, Claire S

4. Allen GA, Gladers B. Approach to the bleeding child. Ped Clin North Am

5. Amorosi EL, Ultmann JE (1966). "Thrombocytopic purpura: report of 16 cases and review of the literature". Medicine (Baltimore) 45: 139-159.

6. Angela M. Cheung et al. (2008), Vitamin $\mathrm{K}$ Supplementation in Postmenopausal Women with Osteopenia (ECKO Trial): A Randomized Controlled Trial, Bunyaratavej N (2007). "[Experience of vitamin K2 in Thailand]" (in Japanese). Clin Calcium 17 (11): 1752-60.

7. Annexin II and Bleeding in Acute Promyelocytic Leukemia ;Jill S. Menell, Gabriela 
8. BESSMAN, J. D. (1986) Automated Blood counts \& differentials .A practical guide. John Hopkins University Press, Baltimore.

9. Biggs R, MacFarlane RG. Hemophilia \& related conditions: survey of 187 cases

10. Bleeding disorders: A common cause of menorrhagia in adolescents Jennifer A. Bevan

11. Bleeding manifestations in severely thrombocytopenic children with immune thrombocytopenic purpura ;Chandra J, Ravi R

12. Diacovo T.G. et al. (1996). "Plateletmediated lymphocyte delivery to high endothelial venules". Science 273 (5272): 252-5. doi:10.1126/science.273.5272.252. PMID 8662511

13. Doctor Cecil Kaplan (2003-11-01). "Fetal and Neonatal Alloimmune Thrombocytopenia". Orphanet Encyclopedia.

14. Epidemiological features of aplastic anaemia in Pakistan ;Adil SN, Burney IA

15. Erpenbeck L, Schön MP (April 2010). "Deadly allies: the fatal interplay between platelets and metastasizing cancer cells". Blood 115 (17): 3427-36.

16. Furie B, Furie BC (2005). "Thrombus formation in vivo". J. Clin. Invest. 115 (12): 3355-62. doi:10.1172/JCI26987. PMC 1297262. PMID 16322780. Boekhout Mussert MJ, Vander Kolk Schaap PJ, Hermans J, Loelijer EA. Tripodi A, Chatarangkul V, Braga M, et al. Results of multicentre study assessing the status of a recombinant thromboplastin.

17. Bowen DJ: Haemophilia A and haemophilia B: molecular insights. Mol Pathol 2002; 55:1

18. Bowie, EJW et al. Mayo clinic laboratory manual of hemostasis, Philadelphia; W.B. Saunders and Co., 1971; 29-33.
19. Campbell, Neil A. (2008) Biology (8th ed.). London: Pearson Education.p. 912.

20. Chromosomal Breakage Study in Aplastic Anemia Patients in India :1D. Jain

21. Clinical audit of inherited bleeding disorders in a developing country ;Sajid $\mathrm{R}$, Khalid

22. Davidson, Stanley; Haslett, C. (2002). Davidson's Principles and Practice of Medicine (19 ed.). Edinburgh: Churchill Livingstone. ISBN 0-443-07036-9. 